\title{
Assessing transmissivity from specific capacity in an alluvial aquifer in the middle Venetian plain (NE Italy)
}

\author{
Paolo Fabbri and Leonardo Piccinini
}

\begin{abstract}
$\overline{\text { ABSTRACT }}$
Defining aquifer permeability distribution accurately over large areas is often debated in hydrogeology. The operational efforts to calculate hydraulic conductivity with classical aquifer tests are significant; however, accurate knowledge of permeability areal distribution is fundamental both from a hydrogeological and a modeling standpoint. This paper presents an empirical relationship between the transmissivity $(T)$ and the specific capacity $(\mathrm{SC})$ values obtained from experimental aquifer and well tests. All experimental values were obtained from $50 \mathrm{~mm}$ wells in middle Venetian plain artesian gravel aquifers. Many other authors have presented empirical relationships between $T$ and SC, but most are related to fissured/karst aquifers, and only a few concern alluvial porous aquifers. Analysis of the $T$ vs. SC relationship standardized residuals shows that a linear relationship produces statistically significant normal residuals compared with an exponential relationship.

Key words | aquifer tests, specific capacity, transmissivity, Venetian plain, well performance equation, well tests
\end{abstract}

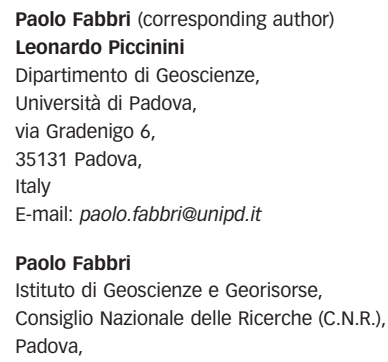

\section{INTRODUCTION}

The estimation of hydraulic conductivity areal distribution is an important problem in groundwater modeling. Although the inverse modeling approach is commonly used, the solutions are not considered to be the most accurate. In large areas the question of accurate transmissivity $(T)$ evaluations is problematic. Given the area under investigation, our interest is in producing a model able to represent possible groundwater movement.

Aquifer tests (pumping well and one or more piezometers) are often complex and expensive; thus, it is necessary to calculate an experimental relationship linking a simpler parameter to $T$. In the literature, more efforts are given to calculating experimental relationships between $T$ and specific capacity (SC) (Rotzoll \& El-Kadi 2008; Verbovsek 2008; Graham et al. 2009), where the SC is defined as the flow rate $(Q)$ divided by the drawdown $(s)$.

Most of these experimental relationships are exponentials and are related to consolidated sediments and hard rocks (Huntley et al. I992; El-Naqa I994; Fabbri I997; Mace I997; Acheampong \& Hess I998; Mace et al. 2000; Dixon \& Custer 2002; Jalludin \& Razack 2004; Hamm et al. 2005; Razack \& Lasm 2007), while only a few of those equations are related to unconsolidated porous sediments (Razak \& Huntley I99I; Christensen I995; Srivastav et al. 2007).

Considering the many experimental relationships presented in the previous cited papers, several issues must first be addressed. First, it is incorrect to consider a relationship that is valid under every geological condition because there are different conditions in different aquifer reservoirs (alluvial, karst, fissured, etc.) and with different well characteristics (diameter, screen, etc.). Second, which kind of drawdown (i.e. aquifer drawdown, well loss or total drawdown) considered in the SC calculation (or estimation) is often not specified, nor how much well losses influence the total drawdown. The type of drawdown is especially important as values from sources with unknown experimental conditions and reliability are available for use.

Jalludin \& Razack (2004) considered different aquifer types and losses by only accounting for aquifer losses in the SC calculation, therefore obtaining a more theoretically correct $T$ value.

In a situation where a large area must be studied and, as in our case hundreds of wells are present, it can be highly useful to obtain the relationships between $T$ and SC under local experimental conditions. Therefore, only increments 
of statistically significant $T$ values in the study area originating from the measured SC values are allowed.

A more areal $T$ distribution allows for better variographic analysis as well as a better geostatistical approach during prediction and simulation.

\section{HYDROGEOLOGY OF THE VENETIAN PLAIN}

The Bacchiglione, Brenta, Piave and Leogra rivers are responsible for the deposition of much of the material that forms the subsoil of the Venetian plain, which is hundreds of metres thick. Along the piedmont belt of the plain, gravelly alluvial fans are laterally penetrated by fans from adjacent rivers. The lithostratigraphical result is an entirely gravelly subsoil throughout the thickness of the high Venetian plain. Because deeper fans have often invaded further areas of the high plain, from the undifferentiated gravel cover, the terminal parts of the fans extend downstream for various distances, producing an alluvial cover that is no longer uniformly gravelly, but becomes composed of alternating layers of gravel and silty clay of swampy, lagoonal or marine origin (Venzo I977).

A large unconfined aquifer is located in this alluvial cover that extends southward from the Pre-Alps as the 'high plain', where the water table is at a maximum depth (about $100 \mathrm{~m}$ below ground level), to a 'middle plain' band that is $2-5 \mathrm{~km}$ wide and several kilometers long, where the water table, being very shallow, intersects the topographic surface. In this band, numerous characteristic plain springs emerge (Figure 1), which are called 'fontanili' (Antonelli \& Dal Prà 1992; Dal Prà et al. 1992; Vorlicek et al. 2004).

This natural drainage system supplies numerous perennial stream-flows, including the Sile River $\left(5-6 \mathrm{~m}^{3} / \mathrm{s}\right)$. This system is a characteristic structure present in the northern Padana plain (Pilla et al. 2006; Cucchi et al. 2008). The relatively homogeneous unconfined hydrogeological unit changes into a multi-layered confined or semi-confined aquifer system (e.g. $T$ ranging from $1 \mathrm{E}-01$ to $1 \mathrm{E}-03 \mathrm{~m}^{2} / \mathrm{s}$ and storativity in confined aquifers from 1E-04 to 1E-06) south of the 'fontanili' belt. Impervious or semi-pervious layers that can be more than $10 \mathrm{~m}$ thick are interbedded with sand and gravel, as seen in the sketch in Figure 2.

The thickness of this aquifer system increases progressively toward the Adriatic Sea. Many public wells of different depths $(100-300 \mathrm{~m})$ have been drilled in the southern part of the study area and have been screened in multilayered aquifer systems to supply the cities of Venice, Mestre and Treviso (about 400,000 people) with drinking water.

The recharge of the unconfined aquifer is mainly from rainfall, irrigation and river dispersion. The
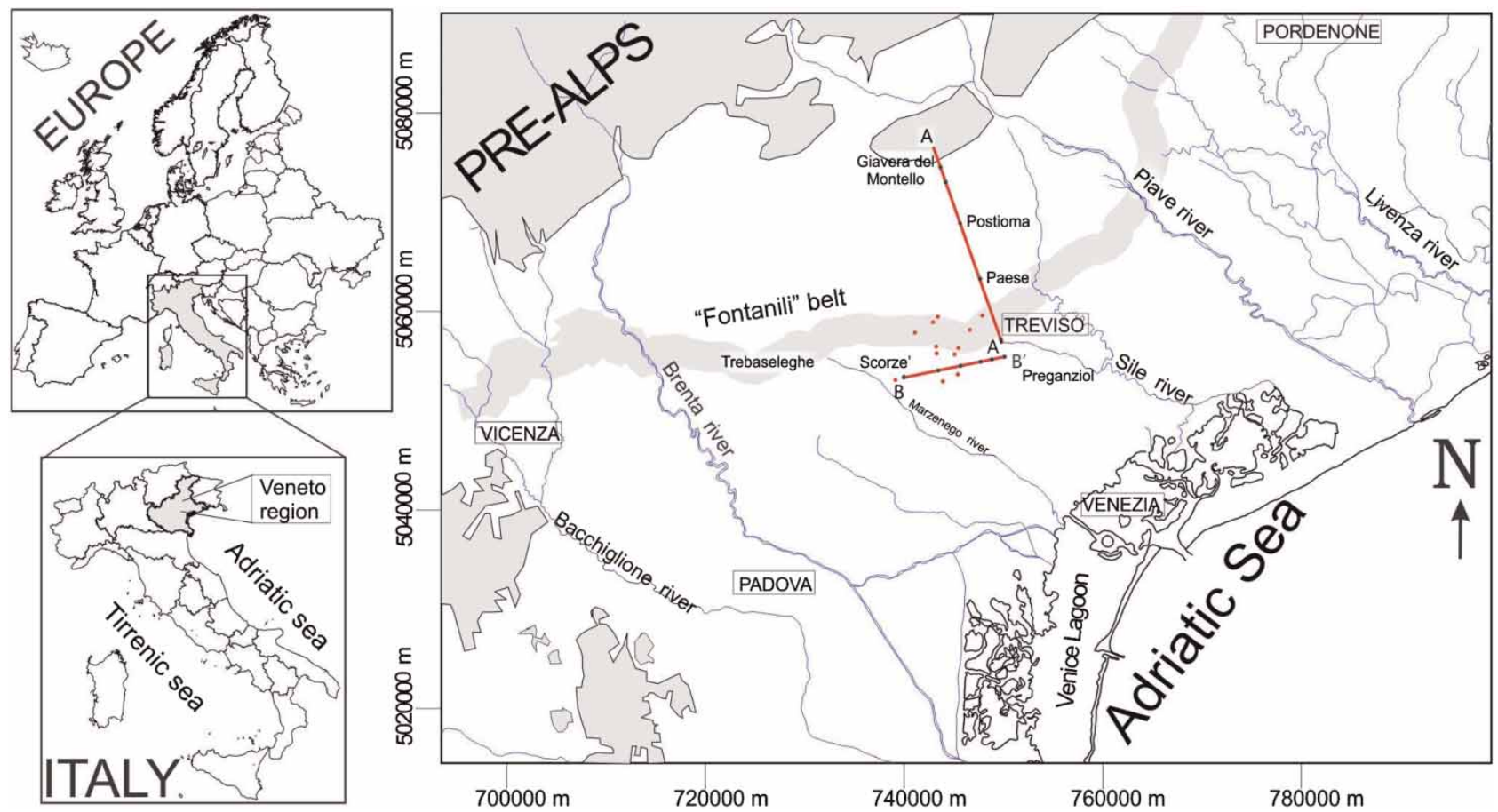

Figure 1 | Sketch of the studied area (coordinates ED50/UTM zone 32N). 


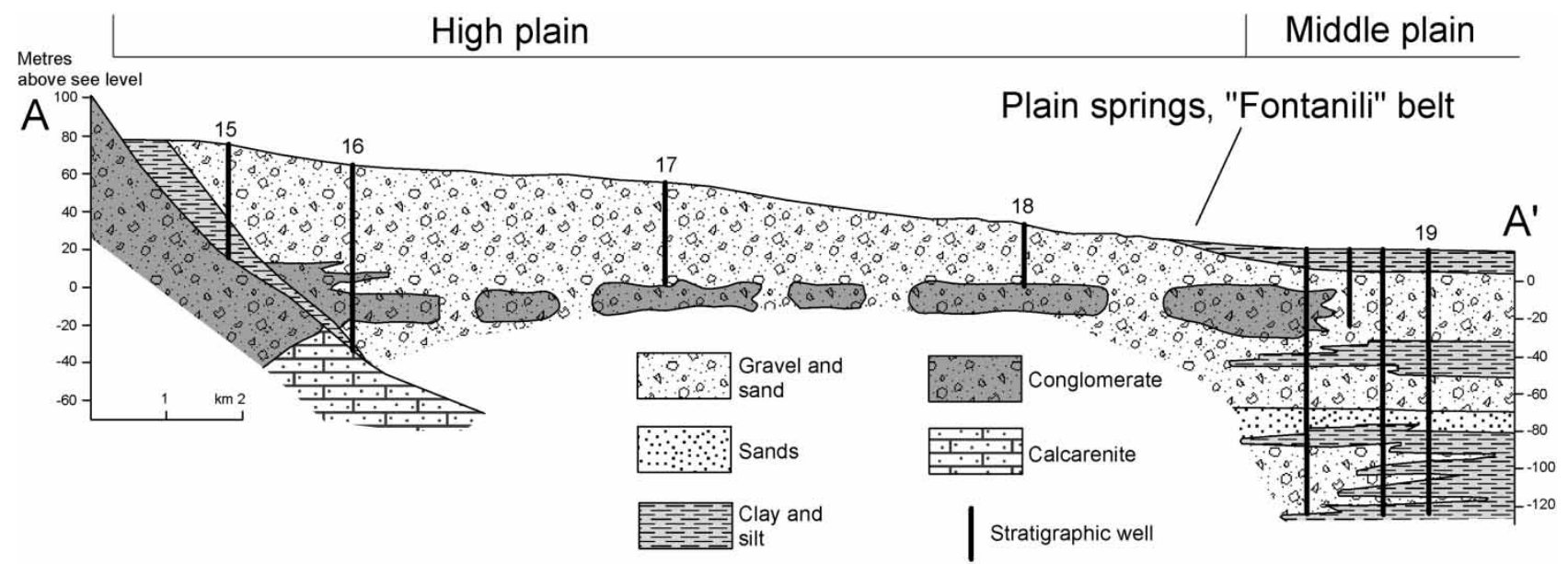

Figure 2 | Cross-section $A-A^{\prime}$; North-South sketch of the Venetian plain (Vorlicek et al. 2004).

recharge action is only effective in the high Venetian plain, where the infiltration of surface waters can reach the unconfined aquifer and, subsequently, the artesian aquifers linked to it.

\section{HYDROGEOLOGICAL SITUATION OF THE STUDIED AREA}

The maximum depth of the lithostratigraphic investigation using wells of both private and public water companies was $320 \mathrm{~m}$. Once several lithostratigraphic cross-sections had been made, 10 superimposed aquifers were identified from 15 to more than $310 \mathrm{~m}$ in depth, and the typical quali-quantitative characteristics of each aquifer were individuated. The 3D aquifer hydrostructure was performed by hydrostratigraphic profiles, both in the North-South and East-West directions (Fabbri et al. 20II). In Figure 1, the trace of the hydrostratigraphical profile presented in Figure 3 can be observed.

In Table 1, the value of the potentiometric level above ground level (i.e. the height at which the water flows without pumping), the average and maximum flow rate (without pumping) and the electrical conductivity of water and its temperature are shown for every aquifer.

\section{$\overline{\text { THEORETICAL BACKGROUND }}$}

SC is defined as the flow rate divided by the drawdown $(Q / s)$, and it is directly correlated with $T$. There have been numerous studies that have considered linear relationships in an unsteady state (Brown 1963; Theis 1963) and under steady state conditions (Thomasson et al. I960). The best known relation between $T$ and SC under steady state conditions starts from Dupuit-Thiem's equation, considering a confined aquifer:

$Q=\frac{2 \pi T\left(s_{1}-s_{2}\right)}{\ln r_{2} / r_{1}}$

where $s=$ drawdowns at piezometers 1 and $2(\mathrm{~m}), Q=$ constant discharge rate at the pumping well $\left(\mathrm{m}^{3} / \mathrm{s}\right), T=$ aquifer transmissivity $\left(\mathrm{m}^{2} / \mathrm{s}\right)$ and $r=$ pumping well distance from piezometers 1 and $2(\mathrm{~m})$. Considering that we take into account only the pumping well, the previous Equation (1) can be simplified as follows:

$s=\frac{\ln R / r_{\mathrm{w}}}{2 \pi T} Q$

where $s=$ drawdown at the pumping well $(\mathrm{m}), R=$ influence radius of the pumping well $(\mathrm{m})$ and $r_{\mathrm{w}}=$ pumping well radius $(\mathrm{m})$. Thus, a simple direct relationship between SC and $T$ will be the following:

$T=\frac{\ln R / r_{\mathrm{w}}}{2 \pi} \mathrm{SC}$

However, using these empirical relationships, does not always produce a good agreement between aquifer test results of $T$ and $T$ values deduced by SC. Even if the results obtained from aquifer tests (pumping well and piezometer) are expected to be different from those calculated by 


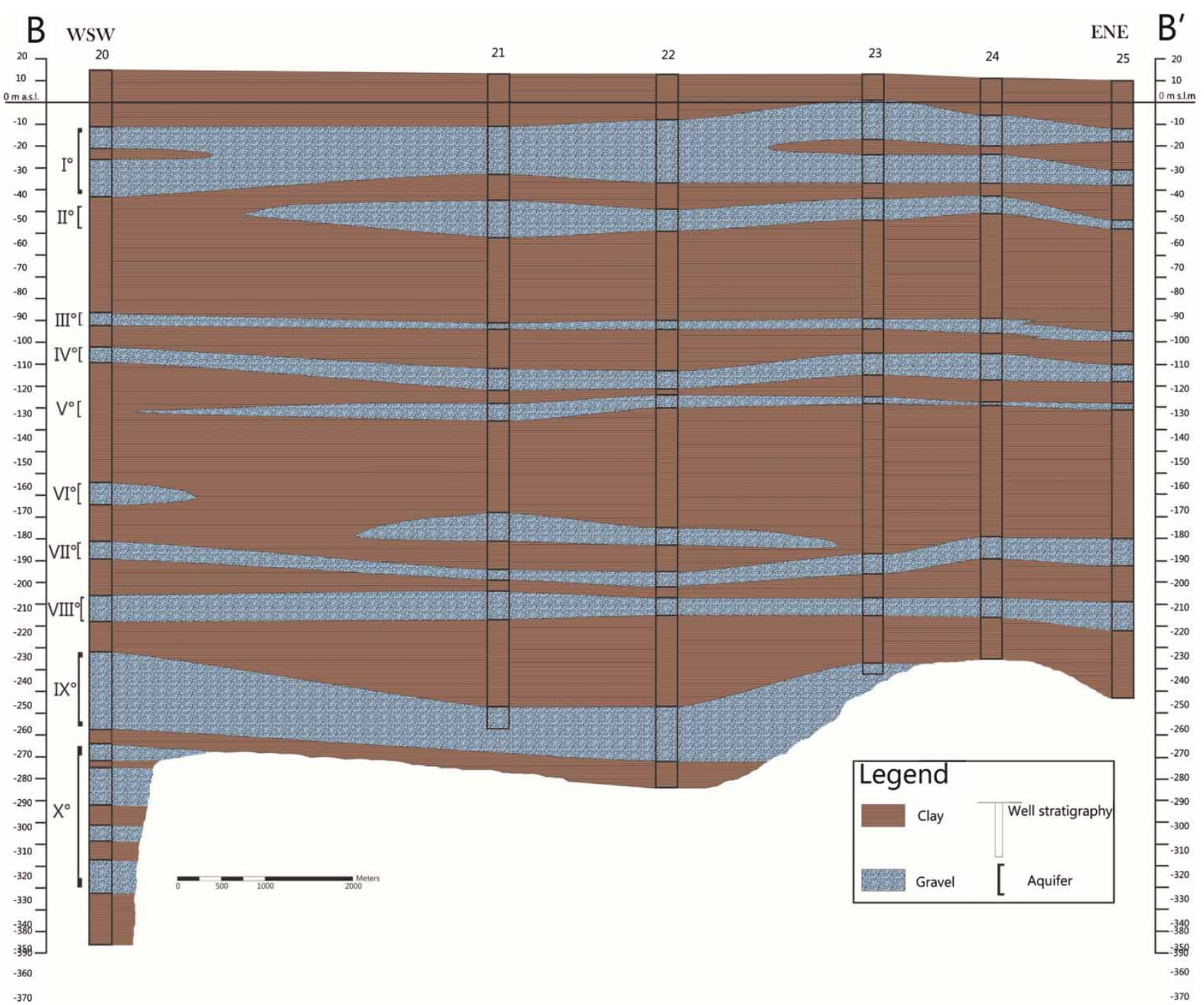

Figure 3 Example of a cross-section from $B-B^{\prime}$. The aquifers are in light blue and specified in Roman numbers, while the aquicludes are in brown (the full colour version of this figure is available in the online version of this paper, at http://www.iwaponline.com/wst/toc.htm).

Table 1 | Aquifer range of depth in metres below ground level ( $m$ b.g.l.) and statistical modal values of the principal parameters of 10 aquifers (Cambruzzi et al. 2010)

\begin{tabular}{lclllll} 
Aquifer & $\begin{array}{l}\text { Depth } \\
(\mathbf{m} \text { b.g.I.) }\end{array}$ & $\begin{array}{l}\text { Head } \\
(\mathbf{m} \text { a.g.I.) }\end{array}$ & $\begin{array}{l}\text { Flow } \\
\text { rate } \\
(\mathbf{I} / \mathbf{s})\end{array}$ & $\begin{array}{l}\text { Flow } \\
\text { rate } \\
(\mathbf{( 1 / s )}\end{array}$ & $\begin{array}{l}\text { Cond. } \\
(\boldsymbol{\mu S} / \\
\mathbf{c m})\end{array}$ & $\begin{array}{l}\text { Temp. } \\
(\mathbf{C})\end{array}$ \\
\hline I & $15-60$ & 0.18 & 0.08 & 0.20 & 340 & 13.0 \\
II & $65-90$ & 0.16 & 0.08 & 0.08 & 350 & 13.6 \\
III & $100-120$ & 1.35 & 0.17 & 0.17 & 330 & 12.7 \\
IV & $130-140$ & 2.40 & 0.29 & 0.70 & 280 & 13.0 \\
V & $145-160$ & 3.15 & 0.50 & 0.50 & 300 & 15.4 \\
VI & $180-200$ & 3.40 & 0.30 & 5.00 & 370 & 13.5 \\
VII & $210-220$ & 3.70 & 0.50 & 3.00 & 350 & 14.0 \\
VIII & $230-260$ & 4.50 & 0.40 & 3.00 & 310 & 16.4 \\
IX & $270-310$ & 6.00 & 0.70 & 3.00 & 320 & 16.5 \\
X & $>310$ & 6.00 & 0.50 & 2.00 & 320 & 17.7 \\
\hline
\end{tabular}

relationships deduced in different geological conditions, frequently widely differing results can be found by taking into account relationships obtained in similar geological conditions, which suggests that other constraints should be considered. For example, the chosen relationships should take into account the local geological conditions (e.g. rock fractures, situations with high $T$ heterogeneity), well structural conditions (e.g. well screen, well diameter), and most importantly, the 'well losses'. In fact, the relationship between drawdown $(s)$ and flow rate $(Q)$ can be expressed as $s=B Q$, where $(s)$ is only the aquifer loss induced into the pumping well by the groundwater flow from the aquifer to the pumping well (i.e. the theoretical aquifer drawdown) and $B=\left(\ln R / r_{W}\right) / 2 \pi T$. Under real field conditions, a $100 \%$ well efficiency is unrealistic because the so-called 'well loss', 
considered part of the 'aquifer loss', always occurs in the pumping well. Well loss determination is another important problem in well hydraulics, and many authors have analyzed this problem, which produces an underestimation of T. Atkinson et al. (I994) described the total drawdown in wells drilled in fractured aquifers as a result of the following four head losses: head losses due to viscous drag as water moves through the aquifer at low velocity in the laminar flow region; secondly, head loss due to non-laminar flow in the immediate vicinity of the well; thirdly, head loss due to the water exiting from the aquifer into the wellbore; finally, the head loss due to the water flowing within the wellbore to the pump intake. The 'well loss' should be represented by the sum of the last three factors. Williams (I985) expressed the total drawdown as a laminar head loss, occurring away from the pumping well, and a turbulent head loss in the vicinity of the well screen. The total drawdown can be represented by the following:

$s_{\text {tot }}=B Q+B^{\prime} Q+B^{\prime \prime} Q^{n}+C Q^{2}+$ minor losses

where $B Q=$ laminar loss in the aquifer, $B^{\prime} Q=$ laminar flow in the damage zone, $B^{\prime \prime} Q^{n}=$ turbulent flow in the filter zone ( $n$ is an exponent, i.e. $1<n<2$ ), and $C Q^{2}=$ well loss. Minor losses are, for example, linked to the convergence of flow lines toward milled slots. The aquifer loss can be calculated by Equation (2), and one of our objectives is to separate the laminar loss, related to the $T$ aquifer, from the turbulent loss independent from the $T$ aquifer, using only aquifer loss to calculate SC.

It is difficult to separate all of these components; thus, practically, the simpler well performance test of Jacob (I947) is usually considered, especially in alluvial aquifers. This is a step-drawdown test in a single well where a constant flow rate is kept until a stabilized drawdown is achieved. This process can be repeated in three steps or more. The well performance test allows the calculation of a classical equation as follows:

$s=B Q+C Q^{2}$

Equation (5) allows separation of the linear components from the quadratic ones. If the well is correctly developed, the $B^{\prime} Q$ component can be considered in $B Q$. If the flow is laminar in the filter zone, it will be $n=1$, and $B^{\prime \prime} Q^{n}$ becomes another linear component. If the flow is turbulent, it will be $n=2$, and $B^{\prime \prime} Q^{2}$ will be considered in the $C Q^{2}$ well loss component.

\section{METHODOLOGY}

The objective of this study is to obtain an experimental relationship between SC and $T$ in a relatively extensive area (i.e. about $150 \mathrm{~km}^{2}$ ) (Figure 4) under its hydrogeological conditions and then calculate $T$ from SC over an even larger area (e.g. $300-400 \mathrm{~km}^{2}$ ) in the confined aquifers of the middle plain.

In order to calculate an experimental relationship in these artesian aquifers, we conducted 28 pumping tests on private wells (diameter of $50 \mathrm{~mm}$ ), 14 of which were aquifer tests in unsteady-state conditions, using a pumping well and a piezometer. Then in these same 14 pumping wells, well tests (well performance test) in steady-state conditions were also carried out. Fourteen pumping tests were related to aquifer IV (wells 2, 3, 6, 8, 11, 13, 14), six to aquifer VII (wells 4, 9, 12), four to aquifer VIII (wells 7, 10) and two to aquifers VI (well 5) and IX (well 1).

In the same well, both an aquifer test and a well performance test were conducted. All of the potentiometric levels were monitored using digital manometers.

During the aquifer tests, the potentiometric level variation in time in a piezometer located near the pumping

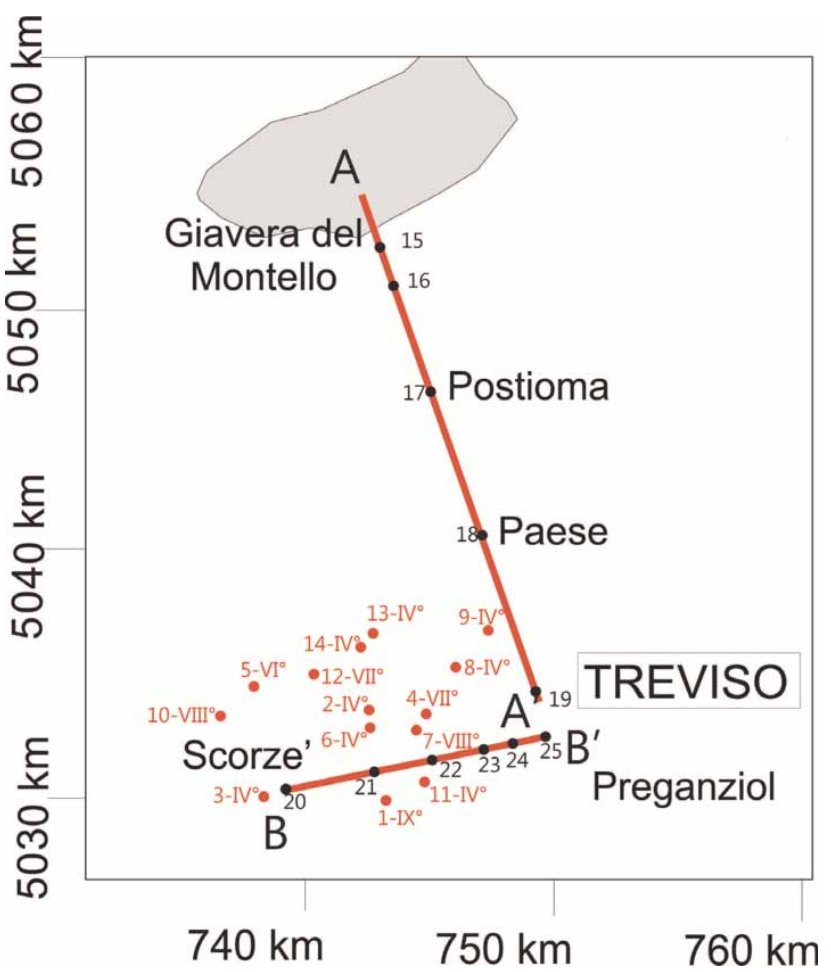

Figure 4 | Detail of Figure 1. Red circles are the 14 tested wells with their numbers and exploited aquifers in Roman numbers; black circles are wells shown in Figures 2 and 3 used only for lithostratigraphic purposes (the full colour version of this figure is available in the online version of this paper, at http://www. iwaponline.com/wst/toc.htm). 
well was monitored; instead, during the well test, the stabilized pressure variation, changing the flow rate into the pumping well, was measured.

The obtained relationships derived from a correlation between the aquifer test $T$ results and the SC, calculating SC only while considering the linear loss $(s=B Q)$ coming from the well performance equation obtained by a step drawdown test.

The analyzed relationships are the following: a lineartype formula $T=m Q / s+b$, and an exponential-type formula $T=m(Q / s)^{b}$, where $Q$ is the flow rate and $s$ represents only the linear loss $(B Q)$.

The fourteen $T$ results coming from aquifer tests (pumping well and piezometer in unsteady-state conditions) were compared to empirical formulas of $T$ vs. SC, derived from our linear estimation and from the literature on both alluvial aquifers (Razak \& Huntley I99I; Srivastav et al. 2007) and fractured metamorphic and crystalline aquifers (Razack \& Lasm 2007). In all the considered experimental relationships, only the linear loss was taken into account when calculating SC.

In this paper all regression analyses were made using the $\mathrm{R}$ code ( $\mathrm{R}$ Development Core Team 20I2), which is a free software environment for statistical computing and graphics.

\section{RESULTS}

Initially, a linear-type relationship based on our experimental data was estimated obtaining:

$T\left(\mathrm{~m}^{3} / \mathrm{s}\right)=4.8 \mathrm{SC}\left(\mathrm{m}^{3} / \mathrm{s} / \mathrm{m}\right)+0.0012$

Figure 5 shows the graphical results of the linear regression with $R=0.84$.

An analysis of standardized differences between experimental $T$ and estimated $T$ values (standardized residuals), which concerns how normally distributed they are, was made to evaluate the goodness-of-fit of the model regression. The QQ-plot in Figure 6 (linear) shows a normal distribution of residuals; in fact, theoretical quantiles of a normal distribution ( $x$-axis) and the quantiles of our standardized residuals ( $y$-axis) are approximately aligned.

Because most of the published experimental relationships are exponential, an exponential relationship was also calculated. The result obtained by the exponential relationship is as follows:

$T\left(\mathrm{~m}^{3} / \mathrm{s}\right)=5\left(\mathrm{~m}^{3} / \mathrm{s} / \mathrm{m}\right) \mathrm{SC}^{1.043}$

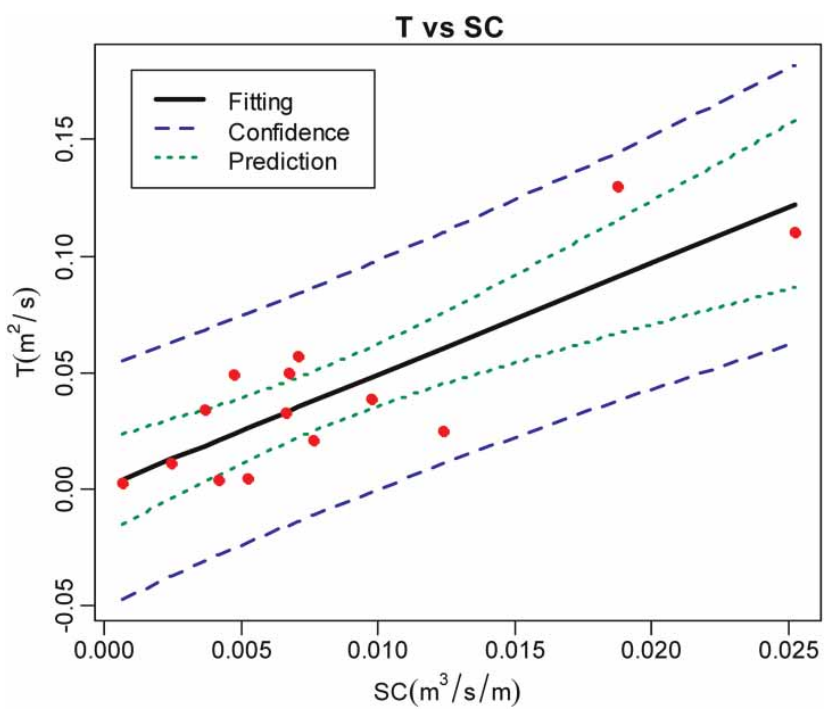

Figure 5 | Linear regression (solid black line), interval of confidence (dashed blue line) and prediction (dashed green line) and the 14 experimental values (red dots) (the full colour version of this figure is available in the online version of this paper, at http://www.iwaponline.com/wst/toc.htm).
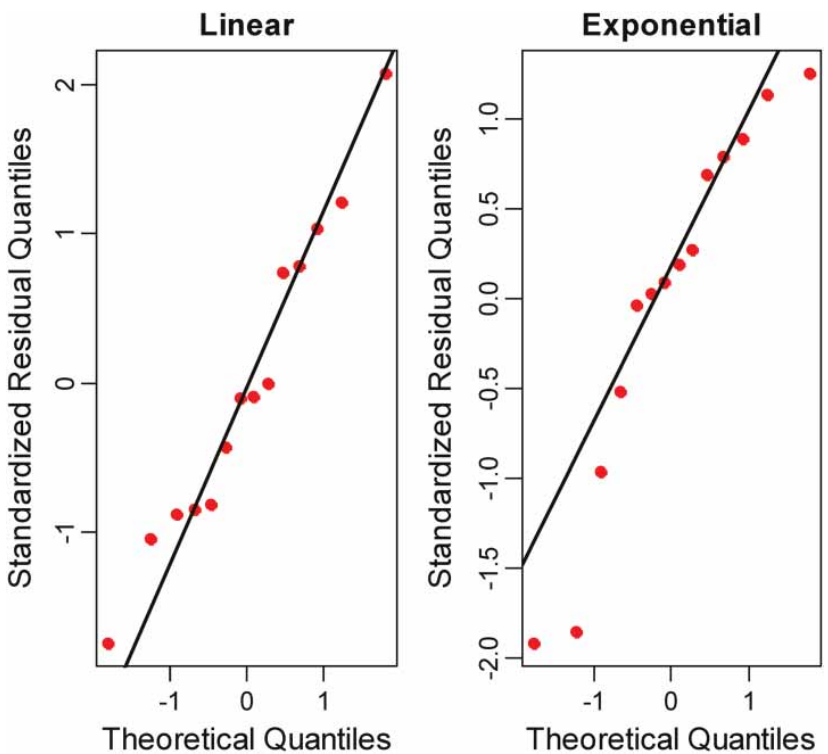

Figure 6 | Analysis of standardized residuals of linear and exponential relationship: the solid black line represents a normal distribution.

which presents a minor $R$ (e.g. $R=0.77$ ) with respect to the previous linear relationship.

A similarly presented relationship but in a heterogeneous alluvial aquifer (Razak \& Huntley I99I) shows a coefficient of 0.36 and an exponent of 0.67 .

A standardized residual analysis of the exponential relationship in Figure 6 shows greater differences from a normal distribution than the standardized residual obtained from the linear relationship (Figure 6). 


\begin{tabular}{|c|c|c|}
\hline Aquifer & $T\left(\mathrm{~m}^{2} / \mathrm{s}\right)$ (aquifer tests) & $T\left(\mathrm{~m}^{2} / \mathrm{s}\right)$ (linear relationship) \\
\hline IV & $4.0 \mathrm{E}-03 \div 1.3 \mathrm{E}-01$ & $1.9 \mathrm{E}-02 \div 1.2 \mathrm{E}-01$ \\
\hline VI & $2.1 \mathrm{E}-02$ & $3.8 \mathrm{E}-02$ \\
\hline VII & $1.1 \mathrm{E}-02 \div 5.7 \mathrm{E}-02$ & $1.3 \mathrm{E}-02 \div 4.8 \mathrm{E}-02$ \\
\hline VIII & $3.3 \mathrm{E}-02 \div 4.9 \mathrm{E}-02$ & $2.4 \mathrm{E}-02 \div 3.3 \mathrm{E}-02$ \\
\hline IX & $2.5 \mathrm{E}-03$ & 4.3E-03 \\
\hline
\end{tabular}

Table 2 presents the range of $T$ deriving from aquifer tests on private wells into the five tested aquifers and results from the presented experimental linear-type relationship.

Most of the published relationships are exponential, but they relate mostly to carbonate/karsts or fissured rocks and less to heterogeneous alluvial aquifers.

Based on our experimental hydrogeological situation, where alluvial homogeneous and confined aquifers with gravelly reservoirs are present, as well as on statistical results, we preferred to consider the linear-type relationship. In comparison, Razak \& Huntley (I99I) found a better regression coefficient $(R=0.63)$ in the exponential relationship than in the linear one $(R=0.40)$, but their results are related to heterogeneous alluvial confined, semiconfined and unconfined aquifers, consisting of clayey-marly and coarse deposits. Moreover Srivastav et al. (2007), in presence of aquifers composed of bedded conglomerates with pebbleto-boulder size clasts in a fine-grained matrix, found a better $R$ in its linear relationship $(R=0.64)$. However, they preferred an exponential relationship $(R=0.59)$ because prediction intervals were negative. In our case the relatively high SC values (taking into account only the linear aquifer loss) which characterize our gravel confined aquifers avoid this problem.

In Figure 7 the $T$ values ( $\mathrm{m}^{2} /$ day) calculated in unsteadysteady state conditions by aquifer tests (pumping well and piezometer) are compared to $T$ obtained from the following: presented linear relation (6), Razak \& Huntley (199I), Srivastav et al. (2007) and Razack \& Lasm (2007) exponential relationships.

Results indicate from the first to the fourth value a $T$ overestimation in all the considered experimental relationships; observing from the fifth to the 14th $T$ value the linear relationship (6) (blue bars) estimates $T$ values much more similar to the aquifer test results (red bars). All $T$ calculated results obtained from exponential relationships show clearly an underestimation of transmissivities compared to our aquifer test results (pumping well and piezometer in unsteady-state conditions).

\section{CONCLUSIONS}

The problem of defining $T$ distribution in a vast area is fundamental to identifying the hydrogeological situation of an area under investigation, and it must be the basis of a correct definition of $T$ from a hydrogeological modeling point of view.

The $T$ distribution in a vast area can be studied by performing numerous aquifer tests, but the calculation of a specific relationship between $T$ and SC under geological and structural conditions allows one to obtain $T$ values

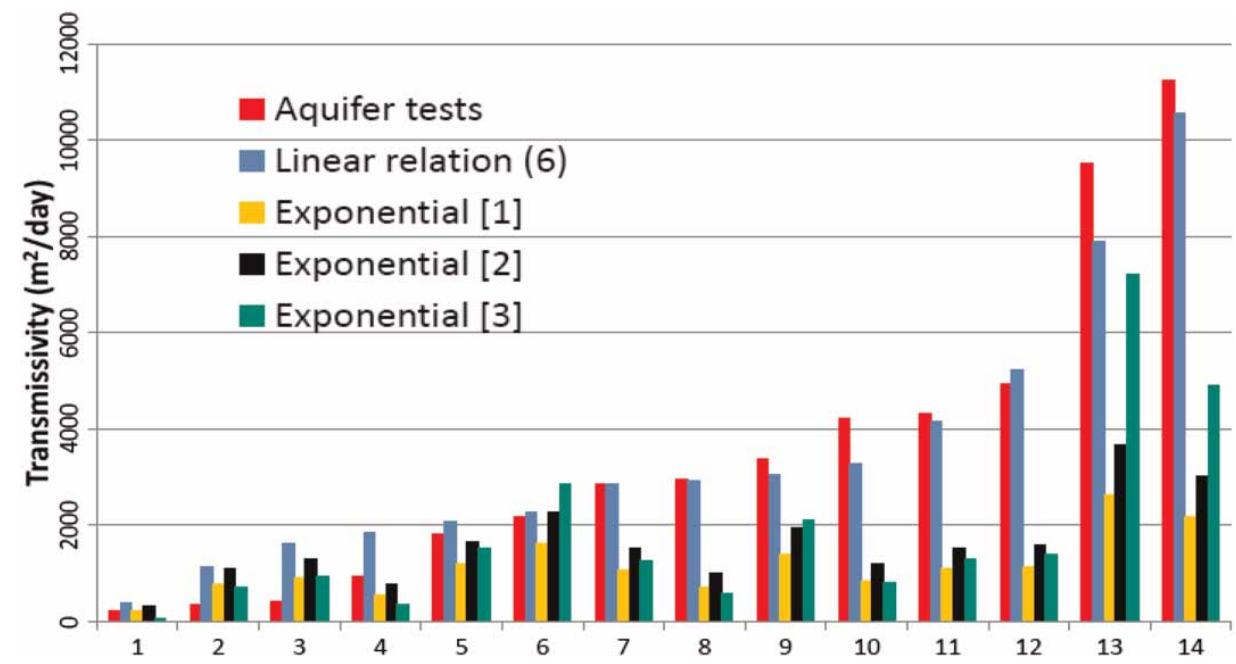

Figure 7 | Comparison of experimental aquifer test results (red bars), linear relationship (6) (blue bars), Razak \& Huntley (1991) [1] (yellow bars), Srivastav et al. (2007) [2] (black bars) and Razack \& Lasm (2007) [3] (green bars) exponential relationships. 
starting from only SC values. The SC values are the most simple to calculate, but the problem is what kind of SC is available. If well performance equations are available, it is correct to consider only the aquifer loss in the SC calculation; if not, it is necessary to carry out a well performance test. Thus, in an area such as the middle Venetian plain, many sites can be tested in terms of SC, and from the calculated relationships, $T$ values can be obtained. Afterward it is possible to predict/simulate the $T$ distribution by a geostatistical procedure and then use the output results in groundwater modeling.

At present, the linear relationship obtained shows a statistically significant regression coefficient $R=0.84$ and regression residuals with a mean equal to zero and normally distributed, which represents a better linear model specification than the exponential one. These results can probably be related to the homogeneity degree present in our experimental conditions; moreover, in the presence of fissured/karst aquifers, $T$ ranges can be much greater due to the heterogeneity degree of the aquifers.

Our resulting experimental relationship appears suitable for diverse hydrogeologic systems such as those found in the middle Venetian plain, characterized by numerous gravelly homogeneous confined aquifers, and for smaller systems such as private artesian wells (50 $\mathrm{mm}$ diameter).

Thus, using a quick and relatively simple test, compared with a more precise but more complex aquifer test, the $T$ distribution in a large area can be more easily investigated.

\section{ACKNOWLEDGEMENTS}

This research was supported by 'GEO-RISKS - Geological, morphological and hydrological processes: monitoring, modeling and impact in the north-eastern Italy', funded by University of Padova. The author would like to thank E. Marcolongo, A. Rosignoli and P. Zangheri for help during experimental measurements and the two anonymous reviewers for their useful comments, which helped to improve the quality of the paper.

\section{REFERENCES}

Acheampong, S. Y. \& Hess, J. W. 1998 Hydrogeologic and hydrochemical framework of the shallow groundwater system in the southern Voltaian sedimentary basin, Ghana. Hydrogeology Journal 6, 527-537.
Antonelli, R. \& Dal Prà, A. 1992 Problems of contamination and protection of underground waters in the Veneto alluvial plain (Northern Italy). Water Science and Technology 24 (11), 66-70.

Atkinson, L. C., Gale, J. E. \& Dudgeon, C. R. 1994 New insight into step-drawdown test in fractured-rock aquifers. Applied Hydrogeology 1, 9-18.

Brown, R. H. 1963 Estimating the transmissivity of an artesian aquifer from the specific capacity of a well. US Geological Survey, Water Supply Pap 1536-I, 336-338.

Cambruzzi, T., Conchetto, E., Fabbri, P., Zangheri, P., Marcolongo, E. \& Rosignoli, A. 20Io Water resources and hydrogeological water balance in the venetian area. Report AATO project, Venezia, Italy.

Christensen, S. 1995 Prediction of log-transmissivity 1: using specific capacity. Nordic Hydrology 26, 1-20.

Cucchi, F., Franceschini, G. \& Zini, L. 2008 Hydrogeochemical investigations and groundwater provinces of the FriuliVenezia Giulia aquifers, northeastern Italy. Environmental Geology 55 (5), 985-989.

Dal Prà, A., Fabbri, P. \& Bortoletto, C. I992 Il sistema idrogeologico artesiano ed il suo sfruttamento nell'area tra Treviso e il fiume Piave (Artesian hydrogeological system and its exploitation between Treviso town and Piave river). Memorie Scienze Geologiche, Università di Padova XLIV, 151-170.

Dixon, S. A. \& Custer, S. G. 2002 Measure of aquifer transmissivity and a test of the hydrogeologic units in Gallatin local water quality district, Gallatin County, Montana. Denver Annual Meeting, Denver, CO, 27-30 October 2002.

El-Naqa, A. 1994 Estimation of transmissivity from specific capacity data in fractured carbonate rock aquifer, central Jordan. Environmental Geology 23 (1), 73-80.

Fabbri, P. 1997 Transmissivity in the geothermal Euganean basin: a geostatistical analysis. Ground Water 35, 5, 881-887.

Fabbri, P., Gaetan, C. \& Zangheri, P. 20II Transfer function-noise modelling of an aquifer system in NE Italy. Hydrological Processes 25, 194-206.

Graham, M. T., Ball, D. F., Dochartaigh, O. \& MacDonald, A. M. 2009 Using transmissivity, specific capacity and borehole yield data to assess the productivity of Scottish aquifers. Quarterly Journal of Engineering Geology and Hydrogeology 42, 227-235.

Hamm, S.-Y., Cheong, J.-Y., Jang, S., Jung, C.-Y. \& Kim, B.-S. 2005 Relationship between transmissivity and specific capacity in the volcanic aquifers of Jeju Island, Korea. Journal of Hydrology 310, 111-121.

Huntley, D., Nommensen, R. \& Steffey, D. 1992 The use of specific capacity to assess transmissivity in fractured-rock aquifers. Ground Water 30, 396-402.

Jacob, C. E. 1947 Drawdown test to determine effective radius of artesian well. Transactions, American Society of Civil Engineers 112, 1047-1064.

Jalludin, M. \& Razack, M. 2004 Assessment of hydraulic properties of sedimentary and volcanic aquifer systems under arid conditions in the Republic of Djibouti (Horn of Africa). Hydrogeology Journal 12, 159-170. 
Mace, R. E. 1997 Determination of transmissivity from specific capacity tests in a karst aquifer. Ground Water 35, 738-742.

Mace, R. E., Smyth, R., Xu, L. \& Liang, J. 2000 Hydraulic conductivity and storativity of the Carrizo-Wilcox aquifer in Texas. Bureau of Economic Geology, The University of Texas at Austin, Austin, TX.

Pilla, G., Sacchi, E., Zuppi, G., Braga, G. \& Ciancetti, G. 2006 Hydrochemistry and isotope geochemistry as tools for groundwater hydrodynamic investigation in multilayer aquifers: a case study from Lomellina, Po plain, SouthWestern Lombardy, Italy. Hydrogeology Journal 14, 795-808.

R Development Core Team 2012 R: A Language and Environment for Statistical Computing. R Foundation for Statistical Computing, Vienna, Austria.

Razak, M. \& Huntley, D. I99I Assessing transmissivity from specific capacity in a large and heterogeneous alluvial aquifer. Ground Water 29, 856-861.

Razack, M. \& Lasm, T. 2007 Geostatistical estimation of the transmissivity in a highly fractured metamorphic and crystalline aquifer (Man-Danane Region, Western Ivory Coast). Journal of Hydrology 325 (1-4), 164-178.

Rotzoll, K. \& El-Kadi, A. 2008 Estimating hydraulic conductivity from specific capacity for Hawaii aquifers, USA. Hydrogeology Journal 16, 969-979.
Srivastav, S. K., Lubczynsky, M. W. \& Biyani, A. K. 2007 Upscaling of transmissivity, derived from specific capacity: a hydrogeomorphological approach applied to the Don Valley aquifer system in India. Hydrogeology Journal 15, 12511264.

Theis, C. V. 1963 Estimating the transmissivity of water table aquifer from the specific capacity of a well. US Geological Survey, Water Supply Pap 1536-I, 332-336.

Thomasson, H. J., Olmsted, F. H. \& LeRoux, E. R. Ig6o Geology, water resources, and usable groundwater storage capacity of part of Solano County, CA. US Geological Survey, Water Supply Pap 1464, 693.

Venzo, S. I977 Quaternary and Upper Neogenic deposits in the low River Piave and Soligo Valley. Memorie Istituto Geologia e Mineralogia, Università di Padova, XXX, pp. 1-62.

Verbovsek, T. 2008 Estimation of transmissivity and hydraulic conductivity from specific capacity index in dolomite aquifer. Journal of Hydrological Engineering 13 (9), 817-823.

Vorlicek, P. A., Antonelli, R., Fabbri, P. \& Rausch, R. 2004 Quantitative hydrogeological studies of Treviso alluvial plain (north east of Italy). Quarterly Journal of Engineering Geology and Hydrogeology 37, 23-29.

Williams, D. E. 1985 Modern techniques in well design. Journal of AWWA 77 (9), 68-74.

First received 3 August 2012; accepted in revised form 21 December 2012 
Copyright of Water Science \& Technology is the property of IWA Publishing and its content may not be copied or emailed to multiple sites or posted to a listserv without the copyright holder's express written permission. However, users may print, download, or email articles for individual use. 